\title{
Reading Arendt in the Russian Context
}

\author{
Alexei Gloukhov \\ Candidate of Philosophical Sciences, Associate Professor, School of Philosophy, \\ National Research University - Higher School of Economics \\ Address: Myasnitskaya str., 20, Moscow, Russian Federation 101000 \\ E-mail: agloukhov@hse.ru
}

\begin{abstract}
Hannah Arendt is well-studied in Russia; her legacy is noticeable in academic discussions. However, her theoretical positions can hardly bring about a significant change in the present state of local political and philosophical affairs. The reason is the same for both the unusual popularity of her theoretical concepts and their lack of practical relevance. Her non-traditional approach to politics seamlessly fits into recurrent patterns of Russian social life which are no-less distant from the established forms of Western political culture. Being uncritically transplanted into different soil, her unorthodox way of thinking about politics found an immediate enthusiastic reception in Russia, but not at the same level of scrutiny as was in the West. Paradoxically, this proves that Arendt's views may confirm the local status-quo, rather than challenging it. In this paper, I will try to explain this paradox by presenting both the elements of her theory that remain under-appreciated by her Russian followers, and her dogmatic positions shared with her school of thought, which can be elucidated by reading them against the Russian context. Arendt's theory features hidden, but distinct, elitist, and liberal tendencies; to some degree, her theory goes well with the Machiavellian character of contemporary Russian politics. However, at the exact point when she finds an unlikely ally in Isaiah Berlin, her normative solutions mostly go unnoticed. On the other hand, reading her texts against the Russian experience exposes some of her preconceptions about human existence, the meaning of political life, and our relations to history, all of which weaken the practical relevance of her thoughts.
\end{abstract}

Keywords: Arendt, Russia, reception, totalitarianism, freedom, normativity

Drawing lessons from Arendt's study of totalitarianism is a required and perplexing challenge for anyone hoping to understand the contemporary political condition in Russia. Today, Arendt's verdict on Stalin's rule remains a focal point in any meaningful discussion of Russia's past. Even those who disagree with her analysis cannot afford to neglect it; even those who believe that they have moved past Arendt often find themselves repeating her conclusions. During Stalin's era, Russia suffered and delivered more than ever. This period was the peak of existential intensity on many levels, while the rest of the Soviet period was a slow, uneven downhill slide. Even today, Russians' political imaginaries must return to those years; they are horrified and spellbound by their recollections of their predecessors' deplorable crimes and miraculous feats, respectively. However, Russia is measured against those years. Arendt was an exceptional thinker who, while diagnosing totalitarianism as an absolute evil, claimed that we could learn something from it (1958a:

\footnotetext{
(с) Глухов А. А., 2019

(с) Центр фундаментальной социологии, 2019
}

DOI: $10.17323 / 1728-192 \mathrm{X}-2019-4-263-283$ 
viii). Not every outside observer is ready to engage with — instead of recoiling from Russia's dark past. Those in Russia do not have the luxury of a choice; they must engage with and learn lessons from their collective past. They are bound to follow Arendt's lead, but doing so is not an easy task. In the first section of this paper, I will present two contextual issues that complicate the appropriation of Arendt's analysis of totalitarianism in contemporary Russia. In the second section, I will discuss this analysis on a conceptual level in relation to her notion of performative freedom, her distrust of normative reasoning, and her explanation of the condition of loneliness.

\section{Two Contextual Paradoxes}

Hannah Arendt retains a special place in contemporary Russian intellectual life, even though Russia never occupied a special place in her political theory. This asymmetry is a curious historical coincidence, but it concerns two paradoxes that we must address if we want to learn from her study of totalitarianism.

The first paradox relates to Arendt's persistent status in Russia as of the one of the most relevant political theorists. For various reasons, which will be explained below, she is a beacon of the academic political discourse in Putin's Russia. ${ }^{1}$ Arendt certainly would have been equally critical of the nationalist politics of the contemporary Russian state as she was of the imperialism of European countries in the first two chapters of The Origins of Totalitarianism (1958a). Another obvious point of contention is her consistent equation of the Nazi and Soviet regimes, which is on the verge of being prohibited by a Russian law. However, these features are ideological, which means that they are less important for her own essentially structural theory.

Arendt's analysis of totalitarianism is difficult to absorb in its entire complexity. On the one hand, she was clear about her final verdict of condemning totalitarian rule as an

1. For example, see a recent issue of the Russian Sociological Review entirely focused on Arendt (Salikov, Yudin, 2018). Arendt is one of a few (if not the only) contemporary political theorists whose legacy justifies opening a dedicated rubric in a leading Russian academic journal such as this one. Within the last few years, a number of dedicated academic discussions on Arendt have been organized in Russia, such as the "Actuality of Hannah Arendt's ideas" conference (Immanuel Kant BFU, Kaliningrad, 04.12.2014), the "Hannah Arendt: Freedom and Responsibility" conference (HSE, Moscow, 19-20.03.2015), the "Hannah Arendt's Legacy and the Present Day" panel discussion (IFRAN, Moscow, 20.10.2016), the "Hannah Arendt on the Limits of the Permissible: Public Sphere, Pluralism and Responsibility" workshop (Moscow School of Social and Economic Sciences, 31.03.2018), and the "Hannah Arendt: Problems of Translation, Problems of Interpretation" workshop (IFRAN, Moscow, 06.06.2019). Two recent publications evaluate the state of Arendtian studies in Russia: Salikov, 2017; Salikov, Zhavoronkov, 2019. In the latter paper, a bibliography of Russian scholarly publications on Arendt cites more entries for the 5 years of 2013-2018 (24 in total) than for all the previous years combined. My paper on Arendt (Gloukhov, 2015) that is not listed there, apparently because it is in English, is also to be counted in the first group. Understandably, the reviewers complain that the state of Arendtian studies and translations in Russia still leaves much to be desired, while granting that she enjoys the status of a first-class thinker and that the interest in her legacy is constantly growing in Russia (Salikov, Zhavoronkov, 2019: 136, 139). As I see it, this level of academic activity focused on a single contemporary thinker's legacy is a lot by Russian standards; the very fact that such a fundamental approach to establishing Arendt's studies in Russia currently being undertaken has no parallel with any other contemporary political theorist, at least for now. 
absolute evil. On the other hand, totalitarian movements fascinated her as a new and unprecedented form of political organization. The duality of her approach escapes some Russian readers who tend to confuse her position with that of undeniably liberal thinkers, such as Isaiah Berlin. Nothing could be further from the truth since Arendt and Berlin shared no mutual intellectual affection (Berlin, Jahanbegloo, 1991). Instead, Arendt found her intellectual peers among dubious anti-liberal thinkers, such as Carl Schmitt. ${ }^{2}$ Unsurprisingly, the contemporary Russian intellectual environment, which favors both Schmitt and Arendt, does not have much use for Berlin's ideas, even though he was the only one of these three thinkers who was genuinely interested in Russia's fate.

In some essential respects, Arendt's vision of political reality is at least compatible with the mainstream political mindset which is currently shared both by the Russian government and its opposition. ${ }^{3}$ The most significant feature of this vision is a tacit disregard for the normative dimension of politics. Although Arendt observed the cause of the dangerous atomization of the masses in the dissolution of traditional political and moral structures, she never proposed a decent legal system as the political ideal. ${ }^{4}$ In contrast, her account of freedom values those spontaneous deviations from norms and laws, which unsurprisingly enjoys an enthusiastic reception in Russia, where the very concept of the rule of law has never been taken for granted. Confronted with this local reality, in which some essential aspects of Arendt's theory are almost universally appreciated along

2. Undeniably, she had ideological differences with Schmitt. They were on the opposite sides in the war against Nazism; they may have had different geopolitical theories (Jurkevics, 2017). See also Filippov, 2015, where the author finds fundamental differences but also a complementarity in their concepts of the political since Arendt places the locus of the political inside the community, whereas Schmitt places it outside of the community. However, their affinity runs on a deeper non-ideological level of tacitly shared axioms of how to approach thinking about political reality. This explains why in The Origins, of all places, Arendt finds an occasion to praise Schmitt's "very ingenious theories about the end of democracy and legal government" that "still make arresting reading" (1958a: 339). She refers constantly to the crucial passages in his 1934 publication State, Movement, People (Schmitt, Draghici, 2001), where we can witness a gradual drift of her research focus from a familiar topic of imperialism to the conceptual discovery of totalitarianism, her major theoretical breakthrough. Today, one can also cite her ample marginalia found in the books from her private library. Schmitt was one of her most extensively studied authors; her marginalia in Schmitt are only outnumbered by those in the great three - Kant, Plato, and Heidegger.

3. To be sure, Alexey Navalny, who is a lawyer by education, relies essentially on available legal instruments in his day-to-day efforts to advance his cause. What I have in mind is rather visions of an ideal political community circulating among Russian intellectuals, where friendship, solidarity, and spontaneity play a more important part than justice, the rule of law, or representative democracy. Giving names is an unfortunate idea for many reasons; therefore, I suggest reading this statement at least as a warning.

4. Benhabib calls it "the missing normative foundations of Arendtian politics" (2003: 193-198). According to her, "the absence of a justification of the normative dimension of the political, that is, of the question of social and political justice in [Arendt's] work, is deeply disturbing." A recent body of research works exploring the normative dimension of Arendt's theory may seem to contradict my conclusion: Goldoni, McCorkindale, 2012; Isaac: 1996; Gündogdu, 2014; Birmingham, 2006. However, the crucial legal innovation suggested by Arendt was "human right to have rights", which clearly transcends the scope and purpose of any particular legal system, thus confirming rather than contradicting this thesis; see also (Gaffney, 2016). In the book On Revolution, Arendt directly connects the loss of the political spirit, "the lost treasure", to establishment of a firm legal framework (2006: 198-229). The point I am making in this paper is less about Arendt in general and more about considering such statements uncritically as helpful against the backdrop of Russian history where the rule of law has always been under attack from other sources. 
the political spectrum, raising doubts regarding whether drawing lessons from her analysis can challenge the established status quo is reasonable.

Arendt neither stated nor resolved the problem surrounding the good political regime, because for her, political life was always about freedom and never about governance. She sharply contrasted the two ways of thinking about politics by comparing the miracle and exceptional phenomenality of freedom with the routine and stultifying character of political administration. The practical downside of her approach is that she discourages thinking about change in the most basic and everyday circumstances of political and social life. By prioritizing exceptional events, Arendt seemingly pushes us to surrender control of our ordinary lives to somebody else. In this respect, she finds natural allies in autocrats who want nothing more than to take on such responsibilities. As such, despite her approach's presumable opposition to the current political regime, students of Arendt are hardly able to challenge it. In contrast, to the extent that it concerns the question of how to change the most basic features of social life, following Arendt may even help reaffirm the authoritarian tendencies in contemporary Russia. Arendt certainly is not the preferred theoretical source of inspiration of the ideologues of the contemporary Russian state who would rather rely on more nationalistic local authors such as Ivan Ilyin or Aleksandr Solzhenitsyn. Nevertheless, the current political regime has proven its ability to think out of box in such matters. In the 20oos, the president's administration encouraged a surge in interest in postmodern philosophy by correctly predicting that its theoretical radicalism would eventually render it politically harmless. After 2016, it has become increasingly obvious that the Russian state has been cynically exploiting the same loophole intrinsic to the key arguments of French theory and of Arendt, e.g., distrust of the truth, reason, science, justice, human rights, the rule of law, and the social contract. This brilliant generation of thinkers believed rather naively that, because they did their best to uproot the entire topic of governance, their theories could never be abused for political profit. By always being more chaotic than rational since the very beginning in the Middle Ages, the Russian state has constantly been contradicting those who look for answers in terms of binary oppositions between politics of the extraordinary and normative orders (Kalyvas, 2008).

The second paradox relates to our desire to learn about Russia's past from a political theorist who was never particularly interested in Russian affairs. Although the matter is complicated and disputed, it must be systematically disentangled.

To begin with, this rule has a few notable exceptions. The Russian Revolution of 1917 was an extraordinary historic event. Being sensitive to the "miracles" of history, Arendt never tired of emphasizing the importance of "the new form of government" born through the Russian Revolution, what she called "the system of people's councils" (1958b: 216). ${ }^{5}$ However, people's councils were not a unique feature of Russian history since the soviets shared this distinction with several other instances of spontaneous revolutionary organizations, such as the Paris Commune of 1871, the German Räte of 1918, and the Hun-

5. In what follows, it is essential to note that her interpretation of people's councils downplayed the importance of social justice in their agendas (Medearis, 2004). 
garian people's councils of 1956. Another possible reason for Arendt to focus primarily on Russian material was the legacy of Vladimir Lenin - an unrealized promise of a revolutionary alternative to totalitarianism. Arendt singled out Lenin among the leaders of 2oth-century mass movements to suggest that a different path for this unprecedented form of political organization was indeed possible. However, she was not consistent in making this point, and the historic material, including Lenin's untimely death, could not provide her with conclusive evidence to support this conjecture.

Irrespective of the importance that we assign to Arendt's study of Russian material in The Origins, a much richer parallel treatment of German affairs has always overshadowed it. Initially, Arendt planned to study only the genealogy of Nazism. In her first draft, the first two parts of the book were intended to present the continuous historical development from European anti-Semitism and imperialism to the emergence of Nazism. She came to understand Nazism as an unprecedented form of political power that was matched only by Bolshevism no earlier than 1947. Nazism and Bolshevism were the only two species of totalitarianism in history. Thus, the published book provides few logical ties between the first two parts of her research on anti-Semitism and imperialism and the third part on totalitarianism. Additionally, these loose ties show that Arendt's material on Russia was not part of her initial project and was only a subordinate topic in her final research (Tsao, 2002). Only one section of her book was exclusively devoted to the Soviet situation; this final chapter was included in a second extended edition after Stalin's death. Even here, with the chapter being entitled "Epilogue: Reflections on the Hungarian Revolution", Arendt was more interested in the recent popular uprising in Soviet Hungary than in the power games within the Communist Party elite in the Soviet Union. Judging by these remarks, Arendt never predicted "the thaw" of the Khrushchev era (1958a: 14). The imbalance in her treatment of the Communist and Nazi sides of the totalitarian story was obvious to Arendt as she planned to expand her study after the first publication of The Origins. However, what she identified as "the most serious gap" in her book was "the lack of an adequate historical and conceptual analysis of the ideological background of Bolshevism" rather than a lack of information from inside the Iron Curtain (Kohn, 2002: v). ${ }^{6}$ Her research plan involved tracing the totalitarian features of Bolshevism to its philosophical roots, thus returning to the ideas of Marx. She drafted almost 1000 pages for this unrealized book, an excerpt of which was posthumously published as Karl Marx and the Tradition of Western Political Thought (2002). Her way of addressing the "gap" in her analysis confirms the general thesis of her book from the outset, i.e., that totalitarianism was an outcome of Western modernity.

However, in demonstrating certain aspects of totalitarianism, Arendt ultimately found the Russian sources to be of paramount importance. For example, she attributed the quality of "selflessness" to members of the totalitarian party who were more concerned about their party membership than their own lives, and this quality was clearly

6. Arendt laments the lack of source material in her review of Waldemar Gurian's book on Bolshevism (1963). Since the only sources are Soviet propaganda, Gurian's strategy was "to concentrate on an analysis of the ideology, avoiding factual narrative as much as possible” (Arendt, 1994: 394). 
modeled on the behavior of the Old Bolshevik Guard during the Moscow show trials of the 1930s. The indiscriminate use of violence and terror, even against agents of the secret police, was unique to Stalin's 'great purges' and, according to Arendt, did not compare to the Night of the Long Knives in Germany. Finally, in the first edition, Arendt's account of concentration camps was primarily based on a 1947 review of conditions in Stalin's gulag, and, to a limited extent, the Nazi camps in Germany, although the scope of the genocide in death camps in Eastern Europe was neglected (Tsao, 2002: 601). In general, Arendt regarded Stalin's Russia as much more advanced in its totalitarian rule than Hitler's Germany. Given the very limited source material available, she based this conclusion on her overall estimates (1994: 348). She had a theoretical concept of "fully developed totalitarian rule" in mind where all the local features disappeared and certain "identical structures reveal[ed] themselves." In her presentation of this concept in The Origins, she alternately relied heavily on both German and Russian material. However, as I show below, the key ingredient in this concept, the totalitarian movement, receives its structural perfection only against the backdrop of the Nazi regime.

Arendt's confidence that all the local features would disappear in the final stage of totalitarian rule correlates with the research method that she was forced to adopt due to her limited access to reliable sources. The theoretical concept of totalitarianism was the envelope that held the factual material emerging from two different directions. With regard to this method's reliability, she made a paradoxical but fully justified decision to take the statements of both Stalin and Hitler literally. A powerful hermeneutic argument informed this decision, to which I will return to later, because not even Arendt appreciated its full potential. Since totalitarianism makes reality correspond to the fiction of the leaders' prophecies, their statements become effective truths and the only truths from the internal perspective of the regimes. After Arendt developed a theoretical concept for the purpose of comparison and collected the highest effective truths in the hierarchy of statements, she could reasonably claim to have built her analysis on a solid foundation (338-339).

Arendt's methodical considerations seem to contradict this paper's argument. For her, discussing the Russian and German cases separately or seeking answers rooted in local historical and political conditions made no sense. Only the final structures of the fully developed totalitarian rule counted, and they were identical. Totalitarianism was an exceptional historical development in both Germany and Russia. However, these anomalies had common historical roots, and they were not exclusively caused by local conditions, but they were conditioned by the hidden forces of the same shared European legacy. Arendt would write that "The subterranean stream of Western history has finally come to the surface and usurped the dignity of our tradition" (1958a: ix). For Arendt, the totalitarianism or the political reality of Stalin's regime pointed to nothing specifically Russian. Therefore, discussing Arendt's application of her general theory to the Russian case is more appropriate than proposing that she had studied a specifically Russian form of totalitarianism. This point is worth stressing whenever we try to reverse-engineer and apply her conceptual framework to contemporary Russian conditions. 
I will address this issue by showing that her structural analysis is a double-edged sword which will not immediately provide us with a meaningful answer. In fact, her ultimate litmus test for political regimes - the challenge of human freedom - was entirely different. In her essay On the Nature of Totalitarianism, a long but unfinished draft of the $14^{\text {th }}$ chapter of the second edition of The Origins, she states from the very beginning that "In order to fight totalitarianism, one need understand only one thing: Totalitarianism is the most radical denial of freedom" (1994: 328). She starts with the diagnosis which she proceeds to explain further in structural terms. Strangely, Arendt does not refer to mass murders as proof of crimes against freedom, as if condemning the regimes purely on the grounds of the incalculable number of victims was too simplistic for her. Numbers do attest to the evil of the regimes, but their denial of freedom is what explains their radicalism. However, Arendt understood freedom in structural terms as a political event that is extraordinary even in a world without genocide. The most radical denial of freedom destroys the very possibility of its existence. It deprives human life of meaning, after which the logical machinery of totalitarianism condemns to death whatever has already been made meaningless. Although her explanation of the initial thesis is complete, it creates the illusion that the explanation is more important than the diagnosis, that is, a structural analysis may contribute more to understanding the destruction of meaning than the destruction itself. Contrary to what is initially obvious, freedom becomes conceptually dependent on the structure of its denial.

Before I demonstrate that freedom is different from what may be proven with a structural analysis, I must lift Arendt's ban on referencing to specific Russian material. In doing so, the same structural features that may have different meaning in a different context are revealed.

In what was mentioned above as an explanation of the compatibility of Arendt's language with mainstream Russian political discourse, the profound negligence of the law was not limited to the post-Yeltsin era. Indeed, the "liberal" Constitution of 1993 so generously enumerated various civil rights, including the right to a favorable natural environment (in the country that covers one-eighth of the Earth's inhabited land area), that nobody really trusted that these rights were sacrosanct. This legal carelessness resembles an intentional inversion of the minimalist concept of basic rights, which such liberals as Isaiah Berlin envisioned to guarantee the robust protection of human freedom under the most adverse conditions.

A comparison of this attitude toward the Russian Constitution with the crucial part of Arendt's analysis of totalitarian rule is even more striking. Both the Soviet and Nazi regimes formally retained their respective constitutional frameworks. Stalin forced the Soviets to adopt a new constitution in 1936, the first year of the "great purge", and Hitler never discontinued the effects of the Weimar Constitution of 1918. For Arendt, the dual character of the political reality where informal dynamics fully dominated but coexisted with the normative order was a distinct feature of totalitarianism because it was absent in the typical modern Western state. Perhaps this moment is the most unfortunate in her analysis because this is where her strategy of a parallel treatment of Russian and Ger- 
man material becomes clearly problematic. Although the proverbial German adherence to Ordnung supports her argument, nothing comparable to this normative foundation of everyday life can be found in Russian history. By contrast, the chaos in the earliest years of the Russian state is legendary. In their invitation letter to Varangian aliens, the Slav tribes perfectly captured the persistent problem that would plague Russia in the centuries to come when they wrote that "Our land is great and rich, but there is no order in it. Come to rule and reign over us" (Cross, Sherbowitz-Wetzor, 1953: 59). Neither the first Varangian princes nor subsequent generations of Russian and Soviet rulers solved the problem of the unstable political order in this part of the world. Stalin's era was no exception to this rule. Arendt prevents us from confusing a totalitarian state with ordinary despotism. Far from being defined as a triumph of Draconian laws, Stalin's regime was the most dynamic and unprecedented period in Russian political history. The exceptional centuries-long persistence of the same political predicament can only have one reasonable explanation, that is, this predicament had become the local definition of normality rather than the exception. The most successful of Russian rulers never considered the lack of order to hinder their ambitions; on the contrary, the intentional creation of chaos and disorder became the inexhaustible source of power for them, marking the precise point at which the Russian and German political traditions diverge toward the extreme limits. The irony of this history is that many of the Russian rulers were German-born or became Germanophiles. However, almost all of them were quick to learn that an extraordinary intervention might bring about success much more easily than a systematic procedure. The term "manual control" epitomizes the most effective way of governing under the current leadership. There is nothing comparable to the normative legacy of ancient Rome that can be found in the foundation of the Russian state. For centuries, the common language of communication, which is the basis of the rule of law, was undermined by the coexistence of the French-speaking elite and their mostly Russian-speaking, uneducated slaves. The golden era of the emerging normative relations in the final decades of the Russian Empire did not last long enough for the legal system to become a vehicle of justice for the millions of peasants and proletarians. Thus, although the totalitarian dynamics of Stalin's regime were exceptional in their intensity and scale, they did not project as dramatically from the historical background as the German case did. As the primary way of thinking about political life for Russian politicians and intellectuals under different regimes, this disregard of the norms and formal procedures of justice is a striking feature of Arendt's political ideal which has little use for the normative concept of politics that is typical in the modern liberal state.

This first section of the paper dealt with a rather curious fact of asymmetry between Arendt's paramount place in contemporary Russian political philosophy and the subordinate place of Russia in her theoretical universe. In the second section, some key Arendtian theoretical ideas are discussed more substantially against the complex backdrop of the Russian political experience. 


\section{Conceptual Problems}

Arendt was a brilliant and passionate political theorist with a keen understanding of political problems. However, she also stuck to certain explanatory patterns which had dubious political implications. She inherited these patterns from her school of thought which included not only Socrates, Aristotle, Augustine, Kant, and Karl Jaspers, but also the Nazi sympathizers Martin Heidegger and Carl Schmitt. Schmitt was one of the Arendt's sources of conceptual inspiration when she was studying the origins of total domination. ${ }^{7}$ For Arendt and Schmitt, the movement was a novel form of political organization that was responsible for the unprecedented features of totalitarianism. In 1933, Schmitt had already clearly outlined the triadic structure of the Nazi state, where the dynamic component of political reality (i.e., the movement) was prioritized over the static component (i.e., the state) while both looked after the apolitical component (i.e., the people) (Schmitt, Draghici, 2001). At that early stage, this Schmittian scheme lacked detail. After the Second World War, Arendt essentially reproduced the same scheme in The Origins by extensively citing recovered Nazi material, all of which confirmed the surprising dynamic features of totalitarian political organization, including the duplication of offices and the shapelessness of the whole structure (1958a: 398). However, the focus of Arendt's analysis differed from that of Schmitt. Schmitt was concerned with the problem of legitimacy. Under the new conditions, the problem must have had a different solution from that of the traditional liberal dual-component structure of political reality, which consisted of the state and the people. Schmitt's solution was the racial idea of a blood-relation that bound the leader to the people. Arendt's main concern was freedom, which was squashed beneath the pressure of terror and ideology. Therefore, on a conceptual level, the same scheme essentially allowed two distinct readings. On the one hand, Schmitt interpreted this power structure as a legitimate government that cared for the people; on the other hand, Arendt interpreted it as a radical form of an illegitimate government that was terrorizing the population. Despite this particular matter being settled, under other circumstances where Arendt relies on structural analysis, her conclusions allow for alternative readings for which Russian material may provide surprising support.

Two moments in her discussion of totalitarian movements are tailored to establish Russia as an exceptional case. The first is that, unlike the Nazi movement with its traceable history before taking power, the Bolshevik movement began, according to Arendt, only after Stalin usurped power by eliminating his competition. To establish a conceptual analogy with the Nazi movement, Arendt had to describe the corresponding preliminary phase of the Communist movement through the material from Eastern European countries. This stretch raises the question of whether the dynamic model of totalitarian movement based on the German material can actually be extended to the Russian case.

The second is that by blaming modernity or the Western philosophical tradition for creating the conditions in which total domination is possible, Arendt falls into the trap of historicism. History becomes a one-way road on which nothing save miracles of free-

7. See also footnote 2 , above. 
dom can prevent humanity from totalitarianism, with Germany and Russia being only the preliminary examples of what is to come. ${ }^{8}$ Specifically, Arendt never explained how a totalitarian state can return to non-totalitarianism. Having only two cases to analyze, with Nazi Germany defeated in the Second World War, and the Soviet Union approaching the height of its global power, Arendt had no reason to account for such a return. However, her incorrect assessment of the post-Stalin era reveals the challenge, which even she had to overcome, of not imagining history as the realization of some logical deduction. In the first printing of the second edition of The Origins, Arendt claimed that the Soviet Union remained a totalitarian state under Khrushchev. This claim, which she was forced to retract in subsequent publications (Tsao, 2002: 601), was entirely logical for Arendt because she considered modernity a destiny that prevented a spontaneous easing of total domination. This directedness of history provided her structural analysis with a definite meaning. However, as the historical process seemingly began moving away from total domination during the "vegetarian time" of the later decades of the Soviet Union, her explanatory method lost its hermeneutic power because it allowed contradictory readings depending on the alleged direction of the historical process. Her method always works in retrospect, when the past is clear and distinct from the present. However, if the present is addressed, as we must do today, and with the future being wide open, the structural analysis helps promote freedom no more than in justifying its restriction. Again, this approach contributes to the preservation of the status quo in contemporary Russian political discourse, as both loyalists and opposing parties can find a foothold in her theory. As this effect is manifested on many levels, I will begin with her concept of freedom, and then proceed with a discussion of her attitude toward normative thinking and her explanation of totalitarianism through the concept of loneliness.

\section{Ambiguities of Performative Freedom}

The power of philosophical concepts is revealed through the evolution of research strategies in subordinate fields, such as social anthropology. The recent generation of anthropologists studying life in the post-totalitarian phase of the Soviet Union employ the conceptual apparatus of post-structuralism, which is, in many respects, consistent with Arendt's structural arguments (Benhabib, 2003: 197). ${ }^{9}$ One of the most acclaimed results of this approach was Alexei Yurchak's book Everything Was Forever, Until It Was No More:

8. Here, Arendt is in line with her former mentor Heidegger, who, after the end of the Second World War, predicted the eventual death of philosophy (1977).

9. What distinguishes Arendt from philosophers such as Gilles Deleuze or Michel Foucault was not her unequivocal condemnation of Hitler's and Stalin's regimes as absolute evils but her conviction that the typical liberal Western state, however evil it has been and would be, was still a better option than a totalitarian state. Unlike Arendt, Deleuze and Foucault rejected Nazism but effectively identified it with every other form of government. Per Deleuze, every state is fascist; per Foucault, every state is racist (Deleuze, Guattari, 2004; Foucault, 2003). A similar indifference was expressed by Vaclav Havel in his famous essay The Power of the Powerless (1978). In Heidegger's anti-modernism, Havel found a source of inspiration for his identification of post-totalitarian states, such as Czechoslovakia, with typical liberal Western states (Havel, Wilson, 1985). 
The Last Soviet Generation (2013). In this section, I present a comparison of Yurchak's and Arendt's performative concepts of freedom as a case study that shows the challenges of reading and applying Arendt's theoretical legacy in the contemporary Russian context.

In a recent interview, Yurchak clearly indicated that his project was designed as an alternative to Arendt's influence on Soviet studies which he associated with a Cold War mentality rooted in the uncritical acceptance of ideological postulates. ${ }^{10} \mathrm{He}$ defines ideology as a rigid set of binary choices between good and evil, etc. According to Yurchak, the post-war Soviet system was neither good nor evil; it was simply different. In particular, the Soviets made space for new forms of freedom, forms not captured by Isaiah Berlin's choice between negative (i.e., liberal) liberty and positive (i.e., Marxist) liberty. Yurchak cites extensive factual evidence in support of his view that informal spaces of performative freedom were indeed developing in the later decades of the Soviet Union. Once the historical process was ripe, the Soviet state disappeared surprisingly quickly; however, after the initial moment of shock, former Soviets were basically prepared to embrace the free life.

Yurchak assumes that his performative concept of freedom is different from the concept that Arendt developed to explain her diagnosis of totalitarianism as the most radical denial of freedom in structural terms. He seems to lump together her account of freedom and that of Berlin's, while in fact his own account is much closer to hers. In presenting his concept, Yurchak refers to Mikhail Bakhtin, John Austin, Jacques Derrida, and Judith Butler. He could have cited Arendt as well because of her almost identical understanding of freedom as virtuosity, which was in statu nascenti when she worked on The Origins and The Human Condition, and eventually perfected in the essay What is Freedom? (1961). Judging by how much Derrida and Butler were indebted to Arendt, Yurchak's conceptual link to Arendt hardly comes as a surprise. In particular, Yurchak's book features striking parallels to Arendt's earlier essay On the Nature of Totalitarianism.

Building on Austin's idea of contrasting constative and performative utterances, Yurchak proceeds to describe late socialism as a duality of rigid universal norms of social behavior and the performative dimensions of each individual act. The rigid carcass of the system was meticulously reproduced, but the same unhealthy fixation of form made the system open to endless performative interpretations. He wrote "The late-socialist system became deterritorialized ... The system was internally mutating toward unpredictable, creative, multiple forms of 'normal life' . . toward greater freedom" (2013). In The Human Condition, Arendt touched on the connection between the performative character of political action and political freedom (1958b). Although the notion of performativity is missing in her essay On the Nature of Totalitarianism, the structural explanation of what freedom that is presented therein is similar to Yurchak's explanation, if we substitute laws for "authoritative discourse" and freedom for "performative shift". In that essay, she wrote, "The stability of laws, erecting the boundaries and the channels of communication between men who live together and act in concert, hedges in this new beginning and

10. In the interview, Yurchak singles out Arendt's work on totalitarianism. See https://gorky.media/intervyu/rossijskoe-obshhestvo-ne-delitsya-na-bolshuyu-vatu-i-malenkuyu-svobodu/ (in Russian). 
assures, at the same time, its freedom; laws assure the potentiality of something entirely new and the pre-existence of a common world, the reality of some transcending continuity which absorbs all origins and is nourished by them" (1994: 342).

Arendt and Yurchak present identical structures of performative freedom emerging on the surface of a stable normative order. Moreover, both imply that this structure of freedom explains its meaning. However, their analyses differ in two essential ways. First, Yurchak's scope was limited to late socialism. He is in better company with Havel, who introduced the term "post-totalitarianism". ${ }^{11}$ Second, Arendt and Yurchak described opposing historical processes. Arendt explained how freedom was gradually destroyed by the rise of total domination. Yurchak described a contradictory process, i.e., how freedom was regained on the way out of the totalitarian condition.

Curiously, despite the differences in their materials, Yurchak and Arendt ultimately present the same concept of freedom, which can be considered both as proof of the concept's validity and as proof of its relative meaningless and redundancy. By itself, the performative concept of freedom does not help draw a line between the pre-totalitarian and post-totalitarian stages. The isolated observation that people enjoy this kind of freedom does not provide any conclusive evidence regarding the quality of regime, from the Weimar Republic in the 1920s, to the Soviet Union in the 1970s, to Russia in the 2010s.

As we are currently deciding about the future based on our understanding of the present situation, the performative concept of freedom, be it Arendt's or Yurchak's, does not help us make an unambiguous judgement, especially in the last case. Yurchak clearly observed that this concept of freedom bridges historical periods. In the introduction to the expanded Russian edition of his book published in 2014 when the memories of a recent wave of political protests were still afresh, he drew a cautious parallel between the contemporary political conditions and life during the era of late socialism. Indeed, as nostalgia for the Soviet Union gradually becomes part of the official ideology, such structural analogies allow double interpretations, depending on which direction one wants to move in history. On the one hand, in line with Yurchak's original argument, these analogies allow a much richer understanding of the existential condition of the last Soviet generations by comparing it to the present conditions in Russia. On the other hand, they allow a rationalization or even a justification of the current infringement on civil liberties as a smooth transition to a different concept of freedom that was (allegedly) enjoyed by our parents. Moreover, any upcoming spontaneous restoration of the late-Soviet Union has already received its conceptual explanation. The same logic of "forever until no more" applies: since the performative patterns of our everyday life already correspond to those in the late-Soviet Union, any surprise restoration of a similar constitutive system in the near future will find the Russian population well prepared for it and not bothered by the change.

11. However, Yurchak rejects this parallel, insisting that, unlike Havel, he does not align his concept of freedom with "grand narratives"; for Yurchak, this alignment was the exact function of Havel's famous "life in truth." 
The similarity between Arendt's and Yurchak's accounts of performative freedom supports my thesis that, in the Russian context, some elements of Arendt's theoretical legacy lose their critical potential and become a means of preserving the status quo. It also exposes a flaw in the concept of freedom shared by Arendt and Yurchak. Indeed, it is only after we are in a position to confront both sides of the concept, corresponding to the opposing currents in the historical process, that we can clearly establish that the concept itself is flawed. This flaw was not sufficiently clear when Arendt described her performative concept of freedom in the context of the pre-totalitarian, law-abiding state (e.g., in On the Nature of Totalitarianism) or in the context of the ancient Greek polis (e.g., in The Human Condition and What is Freedom?). In these cases, freedom was presented as unmistakably precious and, in the last case, even miraculous. Arendt likened freedom to a miracle not only because it was an exceptionally rare event, but also because it had miraculous powers. It is only in relation to a powerful thing can a requirement be imposed to contain its power. Arendt famously challenges us to think of freedom such that it "could have been given to men under the condition of non-sovereignty" (1961: 164). In doing so, she wanted to impose limits on the destructive power of freedom. However, the problem that she wanted us to solve has nothing to do with the concept of freedom. It was her secret maneuver to bring an entirely different concept into play, a concept that she was always reluctant to touch due to its prominent place in philosophy, especially in Plato: justice. Her concept of freedom retains its natural relationship to power. Arendt hinted to this relationship, as she based her interpretation of freedom as virtuosity on the Machiavellian concept of virtue, i.e., the excellence of a successful sovereign. Unlike Yurchak, Arendt would not accept the condition of performative powerlessness, a condition that defined the era of late socialism, as a solution to the problem of freedom.

Yurchak claims to have discovered a novel concept of freedom. In reality, his account has nothing to do with freedom; it sounds much more like a miserable-teenager condition, half-full of resentment and half-sweetened with practical jokes about parents and educators. ${ }^{12}$ Contrary to his claim in the book, former-Soviet people were not prepared for the new autonomous life that befell them. Having been held under Communist Party tutelage for their entire lives, they were suddenly compelled to emerge from this condition of immaturity (recall Kant's famous definition of Enlightenment (Kant, Reiss, 1991: 54)). Unsurprisingly, they failed to meet this challenge of freedom by immediately committing every possible injustice against one another, from civil and nationalistic wars, to economic oppression of the poor, to encroachment on basic liberties, and to ordinary street banditry. A quarter of a century later, many want the same late-Soviet style of immaturity to be imposed on them again. This condition of teenage-like irresponsibility is not a magical bridge that hermeneutically connects the present generations of Russians

12. The prioritization of active over reactive forces is a central piece of Deleuzian political logic. The same should apply to Yurchak's concept of freedom, which is based on, among others, the Deleuzian concept of deterritorialization. However, for Yurchak, the authoritative discourse is a necessary condition for performative responses, which makes his freedom a reactionary force in a clear contradiction to Deleuze's work written in 1962. 
with their Soviet ancestors and younger selves. Rather, this condition is an existential ceiling that has never been cracked in the post-Soviet years; today, it holds the country back.

Although more solidly grounded, Arendt's concept of freedom is no more help than that of Yurchak's in the present-day situation. She refused to think of politics in terms of justice, which she identified with a cold utilitarian approach that was allegedly inaugurated by Plato. She inherited a distrust of theory and science, the normative dimension of politics, and laws and moral principles from her philosophical mentors. However, unlike Heidegger, who was very clearly never concerned about justice, she cared deeply about justice, although she was deprived of and deprived herself of the corresponding political language. Her theory became tangled in two ensuing conceptual misunderstandings. Firstly, she blocked herself from ever properly addressing the problem of justice. Instead, she dressed up justice as a requirement to be imposed on our understanding of freedom. Secondly, she impeded a proper understanding of freedom by prohibiting the identification of freedom and sovereignty. In other words, she never showed how miraculously freedom can translate into the distributive logic of stable laws, norms, principles, and regulations. She regarded the legal and economic dimensions as apolitical; therefore, her theory always had to rely on the binary structural opposition between political freedom and apolitical justice.

\section{The Tyranny of Reason}

Arendt found a historical foundation for this structural method of analysis in Montesquieu's distinction between the structure of government and the principle of action "that sets it in motion" (1994: 329). As mentioned above, she could have learned the same structural distinction between the static power of the state and the dynamic power of the movement from Schmitt. By superimposing these two theories, totalitarianism can be explained through the substitution of the dynamic component when we shift from Montesquieu to Schmitt. The traditional principles of action, such as equality, honor, or even fear, motivated citizens to act in a republic, a monarchy, or a tyranny. Even under tyrannical rule, the people retained their ability to act, though they did so because they feared for their lives. Under the condition of total domination, they were deprived of their abilities to act on any principle of action. Arendt defines totalitarianism as a combination of two components, those of terror and the deductive logic of ideology (1994: 356). Terror extinguishes the inner motivation for action: ideology replaces that inner motivation with external motivations. When a uniform ideology becomes the motor for every action, total domination emerges. To function as the motor of actions, ideology must contain some artificial movement. Arendt discovered such an artificial movement in the logical progress of deductive inference, which, for her, was a far more essential component of every ideology than the actual ideological content. Marxism and Nazism had different ideological contents, but they both featured the same "ice cold reasoning" as Hitler said, according to Arendt (1994: 355). 
Certainly, deductive reasoning only gained prominence in modernity against a backdrop of mass atomization, which, in logical terms, means nothing more than the destruction of all inner considerations that might influence the conclusion. In the end, Arendt exposed textbook rationality as a vehicle of total domination, as though the entire totalitarian state were a single logical argument executed by the leader. After discussing the tyranny of men, Arendt shifts to the "tyranny of logicality", as if logic, not people, killed (1958a: 473). Having defined totalitarianism as the most radical denial of freedom, although trapped in a binary choice between freedom and justice, she had no other option than to construe the theory of totalitarianism as the most radical affirmation of rationalism, normativity, and justice. She would write that "Totalitarian lawfulness pretends to have found a way to establish the rule of justice on earth - something which the legality of positive law admittedly could never attain" (462).

Her decision to expose deductive logic as a vehicle of total domination was biased because her entire school of thought distrusted rationality. Her argument was supported by neither her analysis in previous chapters of the book nor by what we may find in the Soviet material. Earlier, in line with Schmitt, she presented the movement as the most exceptional component of the novel form of government. Consistency would require her to conclude that the movement was literally the motor of total domination. However, the complex nature of the movement - with the cover of façade organizations and the "fluctuating hierarchy" which she so brilliantly described in the $11^{\text {th }}$ chapter of The Origins - makes the chance of any logical deductive process uniformly proceeding through the different layers of access and initiation implausible. Deduction was always paired with hermeneutics, science with prophecy, propaganda with indoctrination, and rationality with mystery. Arendt compared the core of the movement to a secret society, worshipping the leader's "dynamic will" (365). When she explained totalitarian domination through terror and the deductive logic of ideology, she neglected a considerable portion of the totalitarian experience, which was defined by mass enthusiasm and mysterious belonging. Soviet propaganda of the 1930s, exemplified in movies such as Road to Life (1931) directed by Nikolai Ekk or the comedies of director Grigori Aleksandrov, reached the audience through emotion and the promise of a new life rather than through terror or cold logic. Totalitarianism was characterized by this juxtaposition of terror and enthusiasm and logic and mystery. Therefore, an excess of freedom may be partly responsible for the rise in total domination, rather than the tyranny of normative thinking.

At this point, Arendt's curious hermeneutical strategy should be recalled; she interpreted statements by Stalin or Hitler quite literally, regarding them as anchoring truths of totalitarian reality. These statements were also free expressions of the leaders' perverse imaginations. At the zenith of their power, neither Stalin nor Hitler had any reason to not to reveal their true colors. They certainly had to remain mysterious and unpredictable, as arcana imperii is always the greatest reservoir of power. However, although destroying freedom for millions, totalitarian rule created spaces for unprecedented discretion and arbitrariness for those in power. Identifying this unlawfulness with freedom is seemingly illogical, unless, as in Arendt's theory, the law cannot be used as a canon for what 
freedom entails. For Arendt, freedom transcends the law. However, for the same reason, totalitarian power is a radical manifestation of freedom. Arendt recognized this problem; she wanted to define freedom as non-sovereignty, thereby excluding this kind of unlimited arbitrary power from the concept of freedom. However, her circumscription of freedom means that sovereignty is a form of freedom, although a bad one. If freedom and sovereignty were two completely different things, thinking of freedom as non-sovereign would not have been difficult. Arendt did not want to concede that her concept of freedom as a miracle had the same intrinsic issue, for it allowed alternative readings. The miracle was the working means of totalitarian propaganda; the miracle and mystery of extraordinary politics rather than textbook deductive reasoning was the primary cause that millions of people, including many artists, engaged with totalitarian movements. To adequately describe the logical repertoire of totalitarianism, along with the radical power of consecutive reasoning, the power of questioning, destroying, and creating assumptions about human existence that is exercised to a previously unimaginable scale is worth mentioning.

\section{The Loss of Self}

At the individual level, Arendt employed the concept of loneliness as additional evidence of the fatal role played by deductive reasoning (1958a: 474). ${ }^{13}$ She contrasted loneliness with isolation and solitude. Unlike isolation, which relates to the political condition of human beings, loneliness relates to their social intercourse. However, loneliness is not solitude, which is simply the condition of being alone. Arendt insisted that loneliness is most keenly felt in the company of others. Unlike solitude, which allows for inner dialogues, the condition of loneliness is defined as the loss of self. She wrote that "What makes loneliness so unbearable is the loss of one's own self which can be realized in solitude, but confirmed in its identity only by the trusting and trustworthy company of my equals" (477). She concludes that, in the terrifying condition of loneliness, a human being who is deprived of himself or herself, may rely only on purely logical truisms (e.g., two plus two equals four). ${ }^{14}$ Thus, formal logic is exposed as the ultimate foundation of the terror and ideology that prey on human loneliness. This is another example of Arendt's structural thinking, which sounds convincing when applied to Germany rather than Russia. In fact, throughout this argument, Arendt refers to German thinkers such as Hegel, Nietzsche, and Luther (in addition to Cicero, Epictetus, and Augustine).

However, the Russian material seems to contradict her attempts to establish a correlation between the excessive use of deductive logic and the totalitarian condition. Indeed, Stalin allowed logic to be taught in Soviet schools, though to a limited degree, no earlier than 1947. Before 1947, in pre-Revolutionary Russia and immediately after the Revolu-

13. M. Shuster, who promises to give a systematic account of her remarks on loneliness, disputes her description of logical reasoning as unaffected by and related to the totalitarian condition (2012: 494).

14. That her argument is convincing only so far follows from how Descartes memorably challenged the self-evident aspect of mathematical truths in his Meditations. 
tion, the main obstacle to finding oneself was the "trusting and trustworthy company of my equals", whether in the form of a peasant community or kolkhoz or another kind of social environment, rather than an uprooted individuality that blindly relied on deductive reasoning. In general, Arendt's concept of mass atomization which was directly linked to the mechanism of self-loss was inconsistent; adding specifics on the Russian side of the story is just another way of making the same point about her theory which has already been achieved through different means (Baehr, 2007).

The quest for one's own self cannot be accomplished by simply relying on or rejecting the laws of textbook logic. Apparently, neither option was tenable for Socrates, who, in observing the Delphic oracle's mission, continued searching for himself until his dying breath. The trustworthy company of the Athenian citizens was not helpful either. The unlikely parallel between the fate of the ancient Greek philosopher, whom Arendt always admired, and Russian history, in which Arendt was never really interested, helps my argument to become less historically and geographically limited than it might have initially seemed.

Straddling Europe and Asia, Russia is the furthest imaginable object of comparison with the inaugural experience of Western civilization in ancient Greece; however, this comparison remains sufficiently meaningful. Russia was influenced less by the Roman Empire than the majority of Western Europe; it inherited its Western legacy from the Greeks through the Byzantine Empire, not ancient Greece. In a sense, finding invariants that have survived the historical process of translation from ancient Greece to contemporary Russia is similar to tracing the outer limits of the Western world. Disorientation is almost the only real feature shared by ancient Athenian society at the end of the $5^{\text {th }}$ century BC, Europe after the Second World War, and post-Soviet Russian society; this disorientation could not and cannot be compensated by any amount of knowledge of its genealogy and roots. Under such conditions, the Greek answer suggested by Socrates, Plato, and Aristotle consisted of two parts. The first part was to know oneself, which does not quite match Arendt's negative strategy of demonizing deductive reasoning. The classical logic of the Greek philosophers was the cornerstone of the second part of their answer - the establishment of a common language - which was fundamental in providing justice to others. When we find ourselves in the same invariant human condition of disorientation today, blaming deductive reasoning for totalitarianism does not restore any meaning to the world, but knowing oneself and being just toward others can.

\section{Conclusion}

Arendt was a great political realist because she had a gift for clearly identifying political problems. For example, compare her acute sense of reality to the political blindness of her mentor, Heidegger. However, while clearly recognizing such problems, Arendt did not always offer realistic diagnoses and solutions because of the dogmatism intrinsic to her entire school of thought which permeated her theoretical approach. The consistent features of this dogmatism include a distrust of the normative reasoning in all its forms, 
from legislation to science and textbook logic. In many cases, this stance resulted in Arendt's extraordinary theoretical breakthroughs, such as her brilliant exposition of the novel form of the typical political organization of totalitarian movements which could hardly have been achieved without her ability to think of politics in terms similar to those of thinkers such as Carl Schmitt and Martin Heidegger. However, this approach was flawed because it relied, although in a unique way, on the structural features of reality, thereby dispensing with its political meaning. The structural interpretation of phenomena such as freedom and totalitarianism is problematic because it requires the introduction of an external method for reading the findings. For Arendt, this drawback was not an issue because she interpreted the immediate past; her angle was predetermined by the clear understanding that we encounter evil in its most radical form in totalitarianism. Such an unbearable but effective truth is not always given to interpret other historical periods. Under different circumstances, the shortcomings of her approach are exposed. Her engagement with Soviet history which holds an authoritative place in contemporary Russian political discourse reveals these flaws. In the Russian context, her distrust of normative reasoning and the problem of justice - far from being eye-opening - becomes part of a long-standing tradition of neglecting the rule of law which is equally shared by most loyalists and opposing parties; the performative concept of freedom, introduced by Arendt and even shared by some of her Russian critics, is ultimately indifferent to major political changes, such as Russia’s transition from a post-totalitarian society to a quasiliberal society from 1990-2000, and then its reversal which the country is beginning to experience today. Arendt's idea that we can acquire an understanding of politics by returning to the beginning of the Western political experience in ancient Greece should definitely be preserved from her rich theoretical legacy. The Russian parallel may seem out of place here; however, rather than their institutions and philosophical doctrines, the Greeks gave us their way of questioning reality in such a way that asking and giving answers becomes meaningful. In this sense, returning to the Greeks even more than what Arendt accomplished may be the best way to faithfully preserve her legacy.

\section{References}

Arendt H. (1958a) The Origins of Totalitarianism, New York: Meridian Book.

Arendt H. (1958b) The Human Condition, Chicago: University of Chicago Press.

Arendt H. (1961) Between Past and Future: Six Exercises in Political Thought, New York: Viking Press.

Arendt H. (1994) Essays in Understanding, 1930-1954: Formation, Exile, and Totalitarianism, New York: Schocken.

Arendt H. (2002) Karl Marx and the Tradition of Western Political Thought. Social Research, vol. 69, no 2, pp. 273-319.

Arendt H. (2006) On Revolution, London: Penguin.

Baehr P. (2007) The "Masses" in Hannah Arendt's Theory of Totalitarianism. Good Society, vol. 16, no 2, pp. 12-18. 
Benhabib S. (2003) The Reluctant Modernism of Hannah Arendt, Lanham: Rowman \& Littlefield.

Berlin I. (2004) The Soviet Mind: Russian Culture under Communism, Washington: Brookings Institution Press.

Berlin I., Harris I. (2002) Liberty: Incorporating Four Essays on Liberty, Oxford: Oxford University Press.

Berlin I., Jahanbegloo R. (1991) Conversations with Isaiah Berlin, New York: Halban.

Birmingham P. (2006) Hannah Arendt and Human Rights: The Predicament of Common Responsibility, Bloomington: Indiana University Press.

Cross H., Sherbowitz-Wetzor O. P. (1953) The Russian Primary Chronicle, Laurentian Text, Cambridge: The Mediaeval Academy of America.

Deleuze G. (1962) Nietzsche et la Philosophie, Paris: Presses Universitaires de France.

Deleuze G., Guattari F. (2004) Anti-Oedipus, New York: A\&C Black.

Filippov A. (2015) Hanna Arendt i Karl Shmitt: dva ponjatija politicheskogo [Hannah Arendt and Carl Schmitt: Two Concepts of Political]. Sovremennoe znachenie idej Hanny Arendt: Materialy mezhdunarodnoj konferencii [The Contemporary Significance of Hannah Arendt's Ideas: Proceedings of the International Conference], Kaliningrad: Immanuel Kant Baltic Federal University, pp. 52-65.

Foucault M. (2003) Society Must Be Defended: Lectures at the Collège de France, 1975-1976, Basingstoke: Palgrave Macmillan.

Gaffney J. (2016) Another Origin of Totalitarianism: Arendt on the Loneliness of Liberal Citizens. Journal of the British Society for Phenomenology, vol. 47, no 1, pp. 1-17.

Gloukhov A. (2015) Arendt on Positive Freedom. Russian Sociological Review, vol. 14, no 2, pp. 9-22.

Goldoni M., McCorkindale C. (2012) Hannah Arendt and the Law, London: Bloomsbury.

Gündogdu A. (2014) Rightlessness in an Age of Rights: Hannah Arendt and the Contemporary Struggles of Migrants, Oxford: Oxford University Press.

Gurian W. (1963) Bolshevism: An Introduction to Soviet Communism, Notre Dame: University of Notre Dame Press.

Havel V. (1985) The Power of the Powerless. International Journal of Politics, vol. 15, no 3-4, pp. 23-96.

Heidegger M. (1977) The End of Philosophy and the Task of Thinking. Basic Writings, London: Routledge \& Kegan Paul, pp. 373-392.

Isaac J.C. (1996) A New Guarantee on Earth: Hannah Arendt on Human Dignity and the Politics of Human Rights. American Political Science Review, vol. 90, no 1, pp. 61-73.

Jurkevics A. (2017) Hannah Arendt Reads Carl Schmitt's The Nomos of the Earth: A Dialogue on Law and Geopolitics from the Margins. European Journal of Political Theory, vol. 16, no 3, pp. 345-366.

Kalyvas A. (2008) Democracy and the Politics of the Extraordinary: Max Weber, Carl Schmitt, and Hannah Arendt, Cambridge: Cambridge University Press.

Kant I., Reiss H.S. (1991) Kant: Political Writings, Cambridge: Cambridge University Press. 
Kohn J. (2002) Introduction. Social Research, vol. 69, no 2, pp. v-xv.

MacCallum G.C. (1967) Negative and Positive Freedom. Philosophical Review, vol. 76, no 3, pp. 312-334.

Medearis J. (2004) Lost or Obscured?: How V. I. Lenin, Joseph Schumpeter, and Hannah Arendt Misunderstood the Council Movement. Polity, vol. 36, no 3, pp. 447-476.

Salikov A. (2017) Why Arendt?. Russian Sociological Review, vol. 16, no 2, pp. 218-220.

Salikov A., Yudin G. (2018) Hannah Arendt and the Boundaries of the Public Sphere. Russian Sociological Review, vol. 17, no 4, pp. 9-13.

Salikov A., Zhavoronkov A. (2019) Philosophy of Hannah Arendt in Russia. Voprosy filosofi, no 1, pp. 133-145.

Schmitt C., Draghici S. (2001) State, Movement, People, Alexandria: Plutarch Press.

Shuster M. (2012) Language and Loneliness: Arendt, Cavell, and Modernity. International Journal of Philosophical Studies, vol. 20, no 4, pp. 473-497.

Tsao R.T. (2002) The Three Phases of Arendt's Theory of Totalitarianism. Social Research, vol. 69, no 2, pp. 579-619.

Yurchak A. (2013) Everything was Forever, until It was no More: The Last Soviet Generation, Princeton: Princeton University Press.

\title{
Читая Арендт в российском контексте
}

\author{
Алексей Глухов \\ Кандидат философских наук, доцент Школы философии Национального исследовательского \\ университета «Высшая школа экономики» \\ Адрес: ул. Мясницкая, д. 20, г. Москва, Российская Федерация 101000 \\ E-mail: agloukhov@hse.ru
}

\begin{abstract}
Наследие Ханны Арендт в России достаточно хорошо изучено, в академических дискуссиях чувствуется влияние ее мысли. Но ее теоретические позиции едва ли помогают существенно изменить сегодняшнюю локальную ситуацию в политике и философии. В силу одной и той же причины ее идеи популярны в России и не ведут к практическим переменам. Ее оригинальный подход к политике прекрасно ложится на традиционные шаблоны российской политической жизни, которые не менее далеки от устойчивых форм западной политической культуры. Некритически пересаженный на иную почву, ее нетрадиционный способ мышления о политике встречает в России непосредственный и живой отклик, но не столь же суровую критическую проверку, как в странах Запада. Парадоксальным образом это доказывает, что взгляды Арендт могут скорее подтверждать, чем оспаривать локальный статус-кво. В этой статье я привожу объяснение этому парадоксу, указав как элементы ее теории, ускользающие от внимания ее российских последователей, так и догматические положения, присущие в целом ее школе мысли, которые можно выявить благодаря прочтению ее текстов в контексте российской истории. Так, неявно, но различимо в теории Арендт содержатся элитистские и либеральные тенденции, что отчасти согласуется с макиавеллиевским характером современной российской политики. Но как только ее взгляды неожиданно сближаются с позицией Исайи Берлина, эти нормативные
\end{abstract}


решения по большей части оставляются без внимания. В то же время чтение ее текстов в свете российского опыта позволяет выявить ее собственные презумпции относительно человеческого бытия, смысла политического существования и нашего отношения к истории, ослабляющие практическую релевантность ее размышлений.

Ключевые слова: Арендт, Россия, рецепция, тоталитаризм, свобода, нормативность 